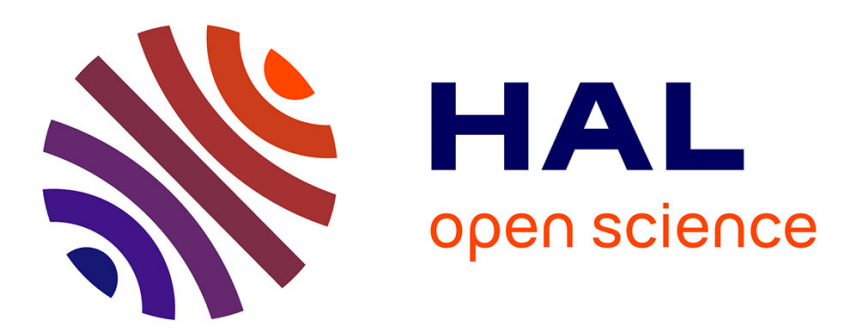

\title{
Characterization and tribological properties of the oxide film formed by eximer laser surface treatment of high chromium tool steel
}

\author{
J.-P. Hirvonen, J. Jervis, R. Lappalainen
}

\section{To cite this version:}

J.-P. Hirvonen, J. Jervis, R. Lappalainen. Characterization and tribological properties of the oxide film formed by eximer laser surface treatment of high chromium tool steel. Journal de Physique IV Proceedings, 1993, 03 (C3), pp.C3-609-C3-609. 10.1051/jp4:1993385 . jpa-00251442

HAL Id: jpa-00251442

https://hal.science/jpa-00251442

Submitted on 1 Jan 1993

HAL is a multi-disciplinary open access archive for the deposit and dissemination of scientific research documents, whether they are published or not. The documents may come from teaching and research institutions in France or abroad, or from public or private research centers.
L'archive ouverte pluridisciplinaire $\mathbf{H A L}$, est destinée au dépôt et à la diffusion de documents scientifiques de niveau recherche, publiés ou non, émanant des établissements d'enseignement et de recherche français ou étrangers, des laboratoires publics ou privés. 


\title{
Characterization and tribological properties of the oxide film formed by eximer laser surface treatment of high chromium tool steel
}

\author{
J.-P. HIRVONEN, J.R. JERVIS* and R. LAPPALAINEN** \\ Metallurgy Laboratory, Technical Research Centre of Finland, 02151 Espoo, Finland \\ * Center for Materials Science, Los Alamos National Laboratory, Los Alamos, NM 87545, U.S.A. \\ ** Department of Physics, University of Helsinki, 00014 Helsinki, Finland
}

\begin{abstract}
An excimer laser operating in air at a wavelength of $248 \mathrm{~nm}$ and a pulse lenght of $25 \mathrm{~ns}$ was used to induce oxidation the surface of high chromium tool steel. Prior to the treatment the steel samples were hardened and tempered. The microstructure consisted of a tempered martensite and carbide precipitates with some retained austenite. After the heat treatment the samples were polished to a mirror like surface finish. A multielement refractive beam homogenizer was used to create a uniformly illuminated square spot of area approximately $0.25 \mathrm{~mm}^{2}$. The samples were scanned in front of the laser spot. The scan speed was chosen for appropriate overlap in order to obtain multiple pulses per position. A laser fluence of approximately $1 \mathrm{~J} / \mathrm{cm}^{2}$ was used. The oxide film was characterized by ion beam analysis (elastic backscattering of protons and $\mathrm{He}^{+}$-ions, nuclear reactions ${ }^{16} \mathrm{O}(\mathrm{d}, \mathrm{p})^{17} \mathrm{O},{ }^{12} \mathrm{C}(\mathrm{d}, \mathrm{p})^{13} \mathrm{C}$, and $\left.{ }^{14} \mathrm{~N}(\mathrm{~d}, \alpha)^{12} \mathrm{C}\right)$ and $\mathrm{X}-$ ray diffraction. Tribological performance of the oxidized surface was evaluated utilizing a pin-on-disc test.
\end{abstract}

